\title{
Article \\ Ethnomycological Investigation in Serbia: Astonishing Realm of Mycomedicines and Mycofood
}

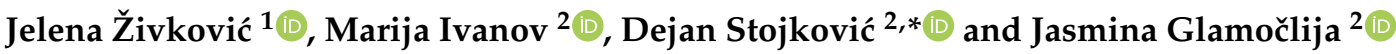 \\ 1 Institute for Medicinal Plants Research “Dr Josif Pancic”, Tadeuša Košćuška 1, 11000 Belgrade, Serbia; \\ jelenazivkovic1@yahoo.com \\ 2 Department of Plant Physiology, Institute for Biological Research "Siniša Stanković" —National Institute of \\ Republic of Serbia, University of Belgrade, Bulevar despota Stefana 142, 11000 Belgrade, Serbia; \\ marija.smiljkovic@ibiss.bg.ac.rs (M.I.); jasna@ibiss.bg.ac.rs (J.G.) \\ * Correspondence: dejanbio@ibiss.bg.ac.rs; Tel.: +381-112078419
}

check for updates

Citation: Živković, J.; Ivanov, M.; Stojković, D.; Glamočlija, J. Ethnomycological Investigation in Serbia: Astonishing Realm of Mycomedicines and Mycofood. J. Fungi 2021, 7, 349. https://doi.org/ 10.3390/jof7050349

Academic Editor: Richard D. Cannon

Received: 31 March 2021

Accepted: 27 April 2021

Published: 29 April 2021

Publisher's Note: MDPI stays neutral with regard to jurisdictional claims in published maps and institutional affiliations.

Copyright: (c) 2021 by the authors. Licensee MDPI, Basel, Switzerland. This article is an open access article distributed under the terms and conditions of the Creative Commons Attribution (CC BY) license (https:// creativecommons.org/licenses/by/ $4.0 /)$.

\begin{abstract}
This study aims to fill the gaps in ethnomycological knowledge in Serbia by identifying various fungal species that have been used due to their medicinal or nutritional properties. Ethnomycological information was gathered using semi-structured interviews with participants from different mycological associations in Serbia. A total of 62 participants were involved in this study. Eighty-five species belonging to 28 families were identified. All of the reported fungal species were pointed out as edible, and only 15 of them were declared as medicinal. The family Boletaceae was represented by the highest number of species, followed by Russulaceae, Agaricaceae and Polyporaceae. We also performed detailed analysis of the literature in order to provide scientific evidence for the recorded medicinal use of fungi in Serbia. The male participants reported a higher level of ethnomycological knowledge compared to women, whereas the highest number of used fungi species was mentioned by participants within the age group of 61-80 years. In addition to preserving ethnomycological knowledge in Serbia, this study can present a good starting point for further pharmacological investigations of fungi.
\end{abstract}

Keywords: ethnomycology; Balkan; food; medicines; mushrooms; macrofungi

\section{Introduction}

Ethnomycology represents an area of ethnobiology that investigates traditional knowledge, as well as cultural and environmental effects, of the association between fungi and man through time and space [1]. Fungi are an important part of ecosystems, where they play many essential roles. They facilitate plants' access to nutrients and water; serve as decay agents that cycle carbon and nutrients through the soil, water and atmosphere; and are major regulators of microbial populations [2]. It is widely known that they have been used historically and globally as food, as well as in medicine. However, ethnomycological knowledge is understudied when compared to local folkloric knowledge about animals and plants. Despite the historical use of fungi since antiquity, ethnological studies of wild mushrooms are a relatively new phenomenon [3].

Mycology has a strong and long tradition in Europe and the knowledge of European species, their distribution, ecology and status is the most extensive in the world [4]. On the other hand, ethnomycological studies have until recently been scarcely performed in Europe. Due to the fact that the usage of fungi as nutraceuticals is increasing, in the last few years an increasing interest in this type of study can be observed [5]. Recent studies have indicated that mushrooms are indeed functional foods, containing components that can contribute to human wellness and mitigate threats and assaults that render the human body vulnerable to several life-threatening diseases, including cardiovascular ailments, cancer and metabolic (diabetes and obesity) and neurodegenerative disorders [6]. Therefore, ethnomycological investigations are of prime importance for the further scientific validation 
of their traditional uses and possible introduction to the development of modern drugs. Furthermore, the documentation of traditional knowledge on the identification of edible wild mushrooms is vital for the application of appropriate management strategies and for the transmission of this knowledge to new generations [7].

As part of Europe, the Balkan peninsula, despite its immense biological and cultural diversity, has begun to attract the attention of ethnobiologists only in the last decades [8]. Thereafter, various studies have addressed folk knowledge in a number of fields, although there are still not many data on the use of fungi in this part of Europe. The richness of fungi and the narrowness of ethnomycological investigations in the Balkan region make it an ideal area for further research.

This study aims to fill the gaps in the ethnomycological knowledge of the Balkan Peninsula, in particular in Serbia. The primary objective was to document fungal taxa that are traditionally used in Serbia. We collected data related to the identification of various fungus species and their edibility, medicinal and food properties, as well as their modes of preparation. Detailed analysis of the literature was also performed in order to provide scientific evidence related to the recorded medicinal use of fungi in Serbia.

\section{Methodology}

\subsection{Ethnomycological Survey}

The ethnomycological survey was carried out during 2016, with participants from different mycological associations in Serbia (Mycological Society of Serbia, Mycological Society of Novi Sad, Ecological Society Studenac, Mushroom Society Šumadija, Mushroom Society Požarevac and the Association of Mushroom and Nature Lovers Vilino kolo). Data were collected randomly using semi-structured interviews. A total of 62 participants were interviewed. The age of participants was between 18 and 80, with an average value of 59 years (Table 1$)$ and the number of male and female participants was $22(35.5 \%)$ and 40 $(64.5 \%)$, respectively.

Table 1. Demographic features of participants.

\begin{tabular}{cc}
\hline Age of Informants & Number of Participants \\
\hline$<20$ & 1 \\
$20-40$ & 9 \\
$41-60$ & 19 \\
$61-80$ & 33 \\
$>80$ & 0 \\
\hline
\end{tabular}

Interviews were performed orally by researchers from the Laboratory of Mycology, Department of Plant Physiology at the Institute for Biological Research "Sinisa Stankovic". Clarifications of the context and the aim of the investigation were presented to the potential participants at the beginning of the surveys. The participants were asked to list all the fungi species they used. In particular, the interview included the following questions: respondent name, sex, age, residence, nationality, profession, local names of the fungi they use, preparation/administration and type of use. For the identification, researchers were equipped with dried fungi samples, photos and literature [9-20]. The validation of biological sample materials that were shown by participants was guided by the exact identification of species by Dr Jasmina Glamočlija, a full research professor in the mycological laboratory of the Institute for Biological Research—National Institute of Republic of Serbia, University of Belgrade, Serbia (Figure 1).

\subsection{Data Analysis}

All fungi cited by participants were taken into account for subsequent analysis. After collecting data, fungal species were ranked based on the number of times that they were mentioned by the participants. Species names and authors' abbreviations were annotated according to the Index Fungorum site (www.indexfungorum.org; the access date 2 March 
2021). The acquired data gathered were grouped in Microsoft Excel and further assessed by quantifying the use reports. Each time a fungus was indicated as "used" this was considered as one "use-report" (UR). Statistical analysis was performed using the Chisquared test of independence, with Yates's correction for continuity.

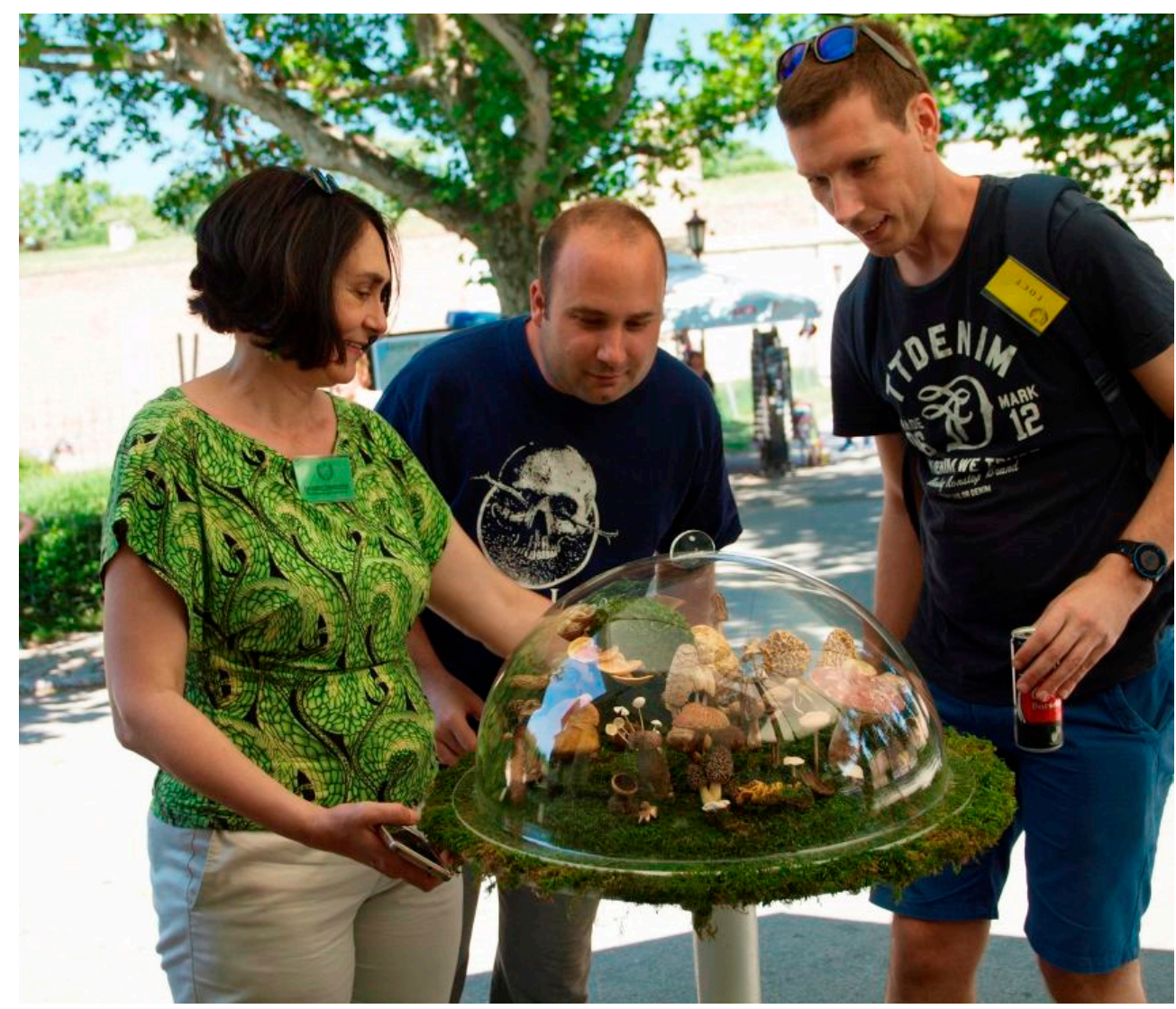

Figure 1. Collection of ethnomycological data in the field.

\section{Results and Discussion}

The results obtained during our study are presented in Table 2, in which fungi used by informants are arranged in the alphabetical order of their names. For each fungus, the scientific name and family, local names, preparation/administration, folk medical uses and total number of use reports were reported. According to our knowledge, this is the first ethnomycological study conducted on the territory of Serbia. This lack of documentation could make local mycological knowledge vulnerable.

In our study, a total of 85 species belonging to 28 families were identified. On average, each interviewed person mentioned nine edible species, with the lowest number of mentioned species at three and the largest at 50. Species with the highest number of use reports were Pleurotus ostreatus, Agaricus leucotrichus, Boletus persoonii, Agaricus macrosporus, Macrolepiota mastoidea, Cantharellus cibarius and Leatiporus sulphureus. The family Boletaceae was represented by the highest number of species (14), followed by Russulaceae (11), Agaricaceae (8) and Polyporaceae (8). The male participants reported the use of the higher number of fungus species compared to women. The Chi-squared test of the number of species reported by various age categories yielded significance. It was observed that the highest number of species was mentioned by participants within the age group of 61-80 years. Older generations had a good knowledge of fungi as compared to the groups below 40 years of age. 
Table 2. Ethomycological data collected on the use of fungi as food and medicines (+ stands for recorded use; / stands for not recorded use).

\begin{tabular}{|c|c|c|c|c|}
\hline Scientific Name, Family Name & Local Serbian Name & Food Use & Medicinal Use & Number of Use Reports \\
\hline $\begin{array}{l}\text { Agaricus campestris sensu Cooke 1885, } \\
\text { Agaricaceae }\end{array}$ & rudnjača & + & / & 4 \\
\hline $\begin{array}{l}\text { Agaricus cupreobrunneus (Jul. Schäff. and Steer) Pilát 1951, } \\
\text { Agaricaceae }\end{array}$ & braon šampinjoni & + & / & 1 \\
\hline $\begin{array}{l}\text { Agaricus leucotrichus F.H. Møller 1952, } \\
\text { Agaricaceae }\end{array}$ & beli šampinjoni & $\begin{array}{l}\stackrel{+}{\text { Mushroom pie; fried mushrooms, }} \\
\text { stuffed mushrooms }\end{array}$ & / & 41 \\
\hline $\begin{array}{c}\text { Agaricus macrosporus (F.H. Møller and Jul. Schäff.) Pilát 1951, } \\
\text { Agaricaceae }\end{array}$ & $\begin{array}{l}\text { kračun, } \\
\text { veliki šampinjon }\end{array}$ & $\begin{array}{l}+ \\
\text { Mushroom pie; fried mushrooms, } \\
\text { stuffed mushrooms }\end{array}$ & / & 32 \\
\hline $\begin{array}{l}\text { Amanita caesarea (Scop.) Pers. 1801, } \\
\text { Amanitaceae }\end{array}$ & blagva & $\begin{array}{c}+ \\
\text { Fresh in salads; bread spread prepared } \\
\text { using fresh mushrooms, lemon juice, } \\
\text { pepper and garlic; fried on butter }\end{array}$ & / & 9 \\
\hline $\begin{array}{c}\text { Amanita rubescens (Pers. ex Fr.) Gray 1797, } \\
\text { Amanitaceae }\end{array}$ & biserke & + & / & 3 \\
\hline $\begin{array}{l}\text { Amanita vaginata (Bull.) Lam } 1783 \\
\text { Amanitaceae Rose, Amanitaceae }\end{array}$ & siva preslica & + & / & 1 \\
\hline $\begin{array}{c}\text { Armillaria mellea sensu Massee 1871, } \\
\text { Physalacriaceae }\end{array}$ & puze, mednjače & $\begin{array}{l}\text { Cooked and mixed with paprika } \\
\text { during ajvar preparation }\end{array}$ & / & 9 \\
\hline $\begin{array}{l}\text { Armillaria ostoyae (Romagn.) Herink 1973, } \\
\text { Physalacriaceae }\end{array}$ & puze, mednjače & + & / & 4 \\
\hline $\begin{array}{l}\text { Armillaria tabescens (Scop.) Emel 1921, } \\
\text { Physalacriaceae }\end{array}$ & grmače & + & / & 2 \\
\hline $\begin{array}{c}\text { Auricularia auricula-judae (Bull.) Quél. 1886, } \\
\text { Auriculariaceae }\end{array}$ & judino uvo & Used fresh in salads or cooked in soups & $\begin{array}{l}\text { Used to improve blood vessel function: } \\
\text { - } \quad \text { mixed with garlic, parsley leaves and } \\
\text { apple vinegar } \\
\text { - } \quad \text { fea } \\
\text { fresh mushrooms (2-3 pieces) should } \\
\text { be nibbled }\end{array}$ & 8 \\
\hline $\begin{array}{l}\text { Boletus edulis Bull. 1782, } \\
\quad \text { Boletaceae }\end{array}$ & letnji vrganj & $\begin{array}{c}+ \\
\text { Used in goulash or fried in butter with } \\
\text { pepper; in mushroom pie, for soups }\end{array}$ & $\stackrel{+}{+}$ Used for strengthening the immune system & 38 \\
\hline $\begin{array}{l}\text { Boletus aereus Bull 1789, } \\
\quad \text { Boletaceae }\end{array}$ & crni vrganj & $\begin{array}{c}+ \\
\text { Used in goulash or fried in butter with } \\
\text { pepper; in mushroom pie, for soups }\end{array}$ & / & 18 \\
\hline
\end{tabular}


Table 2. Cont.

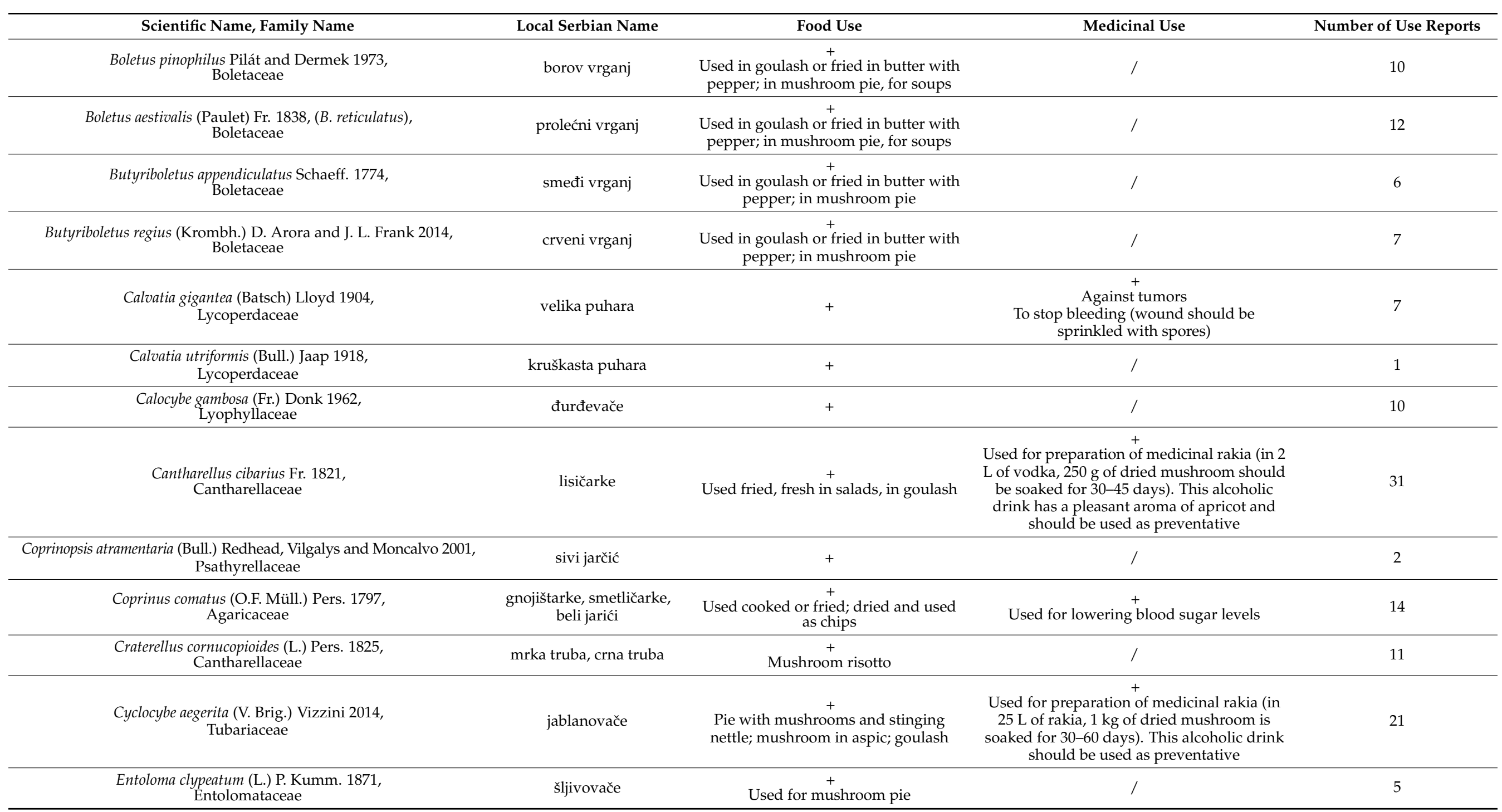


Table 2. Cont

\begin{tabular}{|c|c|c|c|c|}
\hline Scientific Name, Family Name & Local Serbian Name & Food Use & Medicinal Use & Number of Use Reports \\
\hline $\begin{array}{l}\text { Fistulina hepatica (Schaeff.) With. 1792, } \\
\text { Fistulinaceae }\end{array}$ & jetrenjače, volovski jezik & $\begin{array}{l}+ \\
\text { Fresh in salads; used for preparation of } \\
\text { sweet pie; pouched desert prepared } \\
\text { from F. hepatica, Leatiporus sulphureus } \\
\text { and Sarcoscypha cocciena }\end{array}$ & / & 6 \\
\hline $\begin{array}{l}\text { Flammulina velutipes (Curtis) Singer 1951, } \\
\text { Tricholomataceae }\end{array}$ & zimska panjevica & + & / & 4 \\
\hline $\begin{array}{l}\text { Fomes fomentarius (L.) Fr. 1849, } \\
\text { Polyporaceae }\end{array}$ & trud & / & $\begin{array}{l}\quad+ \\
\text { - } \quad \text { As a preventative: } \\
\text { tea (one spoon of dried and ground } \\
\text { mushroom should be cooked in 1 L of } \\
\text { water for } 30 \text { min) }\end{array}$ & 1 \\
\hline $\begin{array}{l}\text { Fomitopsis betulina (Bull.) B.K.Cui, M.L.Han and Y.C.Dai 2016, } \\
\text { Fomitopsidaceae }\end{array}$ & brezina guba & $\begin{array}{l}\text { Mushroom should be eaten while still } \\
\text { young }\end{array}$ & $\begin{array}{l}\text { As a preventative: } \\
\text { - } \quad \text { tea (one spoon of dried and ground } \\
\text { mushroom should be cooked in } 1 \mathrm{~L} \text { of } \\
\text { water for } 30 \mathrm{~min}) \\
\text { tincture }(100 \mathrm{~g} \text { of mushroom should be } \\
\text { soaked in } 1 \mathrm{~L} \text { of brandy or vodka and } \\
\text { left for } 21 \text { days, with daily shaking. Af- } \\
\text { ter this period, tincture should be de- } \\
\text { canted and mushrooms further boiled } \\
\text { in } 3 \mathrm{~L} \text { of water for } 3 \mathrm{~h} \text {. Tincture and } \\
\text { tea should be mixed after cooling and } \\
\text { this preparation should be drunk } 1 \text { to } 3 \\
\text { times per day in small cups) }\end{array}$ & 1 \\
\hline $\begin{array}{l}\text { Ganoderma applantatum (Pers.) Pat. 1887, } \\
\text { Polyporaceae }\end{array}$ & pljosnata sjajnica & / & $\begin{array}{l}+ \\
\text { For strengthening the immune system: } \\
\text { tea (mushroom should be boiled in wa- } \\
\text { ter for } 10 \mathrm{~min})\end{array}$ & 1 \\
\hline $\begin{array}{l}\text { Ganoderma atkinsonii syn Ganoderma carnosum Pat. 1889, } \\
\text { Polyporaceae }\end{array}$ & jelina sjajnica & / & $\begin{array}{l}\text { For strengthening the immune system: } \\
+ \text { tea (mushroom should be boiled in } \\
\text { water for } 10 \mathrm{~min})\end{array}$ & 1 \\
\hline
\end{tabular}


Table 2. Cont.

For strengthening the immune system cancer treatment:

- $\quad$ tea (recipe 1)-mushroom should be boiled in water for 10-15 $\mathrm{min}$, or it could be soaked in cold water for $5 \mathrm{~min}$ and then cooked for $30 \mathrm{~min}$; this tea is also used as a base for preparation of Turkish coffee

- $\quad$ alcoholic tincture (recipe 1)-100 g of mushroom should be soaked in $1 \mathrm{~L}$ of brandy or vodka and left for 21 days, with daily shaking. After this period the tincture should be decanted and mushrooms further boiled in $3 \mathrm{~L}$ of water for $3 \mathrm{~h}$. The tincture and tea should be mixed after cooling and this combined preparation drunk 1 to 3 times per day in small cups)

- $\quad$ tea (recipe 2) - chopped (fresh or dried) mushroom should be put in a dish (up to $20 \%$ of the volume), poured over with water and left overnight. In the morning, the mushroom should be cooked in the same water for $3 \mathrm{~h}$ (one informant mentioned that the same mushroom can be used for cooking three times). After cooling, the obtained extract should be divided in smalle amounts and left in the refrigerator. The obtained ice cubes should be further mixed with lemonade or mineral water and taken regularly.

- alcoholic tincture called Ganodermovaca (recipe 2)-mushroom should be chopped into tiny pieces, put in glass jar or bottle and poured over with rakia obtained from grapes, apples or pears. After one month of standing pears. After ould be decant standing process should be repeated. This time it prould stand in rakia $2-3$ months. Two extracts should be mixed and taken regularly, alone or in combination with previously mentioned ice cubes. 
Table 2. Cont

\begin{tabular}{|c|c|c|c|c|}
\hline Scientific Name, Family Name & Local Serbian Name & Food Use & Medicinal Use & Number of Use Reports \\
\hline $\begin{array}{l}\text { Grifola frondosa (Dicks.) Gray 1821, } \\
\text { Meripilaceae }\end{array}$ & zec gljiva & + & / & 7 \\
\hline $\begin{array}{l}\text { Hericium coralloides (Scop.) Pers. 1794, } \\
\text { Hericiaceae }\end{array}$ & bukova brada & + & / & 1 \\
\hline $\begin{array}{l}\text { Hygrophorus marzuolus (Fr.) Bres. 1893, } \\
\text { Hygrophoraceae }\end{array}$ & martovka & + & / & 2 \\
\hline $\begin{array}{l}\text { Limacium russula (Schaeff. ex Fr.) Ricken 1915, } \\
\text { syn. Hygrophorus russela, Hygrophoraceae }\end{array}$ & medenka & + & / & 1 \\
\hline $\begin{array}{l}\text { Hydnum repandum L. (1753), } \\
\text { Hydnaceae }\end{array}$ & ježevice & $\begin{array}{c}\text { Prepared with sour dressing; deep } \\
\text { fried }\end{array}$ & / & 2 \\
\hline $\begin{array}{l}\text { Infundibulicybe geotropa (Bull.) Harmaja 2003, } \\
\text { syn Clitocybe geotropa Tricholomataceae }\end{array}$ & martinčica & + & / & 1 \\
\hline $\begin{array}{l}\text { Lactarius deliciosus (L.) Gray 1821, } \\
\text { Russulaceae }\end{array}$ & rujnice & 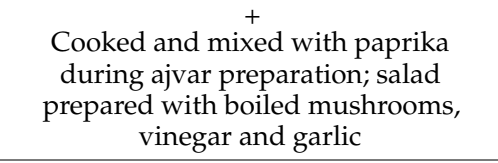 & / & 5 \\
\hline $\begin{array}{l}\text { Lactarius deterrimus Gröger 1968, } \\
\text { Russulaceae }\end{array}$ & smrekina mlečnica & Deep fried or grilled & / & 3 \\
\hline $\begin{array}{l}\text { Lactarius pergamenus syn Lactiflus glaucescens (Crossl.) Verbeken 2012, } \\
\text { Russulaceae }\end{array}$ & mlečnica & Deep fried or grilled & / & 1 \\
\hline $\begin{array}{l}\text { Lactarius piperatus (L.) Pers. 1797, } \\
\text { Russulaceae }\end{array}$ & paprenjače, bele ljute, & Deep fried or grilled & / & 1 \\
\hline $\begin{array}{c}\text { Lactarius salmonicolor R. Heim and Leclair 1953, } \\
\text { Russulaceae }\end{array}$ & jelova mlečnica & Deep fried or grilled & / & 2 \\
\hline $\begin{array}{l}\text { Lactarius semisanguifluus R. Heim and Leclair 1950, } \\
\text { Russulaceae }\end{array}$ & jelina rujnica & Deep fried or grilled & / & 1 \\
\hline $\begin{array}{l}\text { Leatiporus sulphureus (Bull.) Murrill 1920, } \\
\text { Polyporaceae }\end{array}$ & šumsko pile & $\begin{array}{l}\text { + } \\
\text { Used in goulash; breaded and fried; } \\
\text { poached desert prepared from } \\
\text { Fistulina hepatica, L. sulphureus and } \\
\text { Sarcoscypha coccinea. } \\
\text { One informant suggested the use of } \\
\text { mushrooms grown on wild cherry trees } \\
\text { due to their special taste and intensive } \\
\text { color. Furthermore, only young and soft } \\
\text { mushrooms should be used. }\end{array}$ & / & 29 \\
\hline
\end{tabular}


Table 2. Cont.

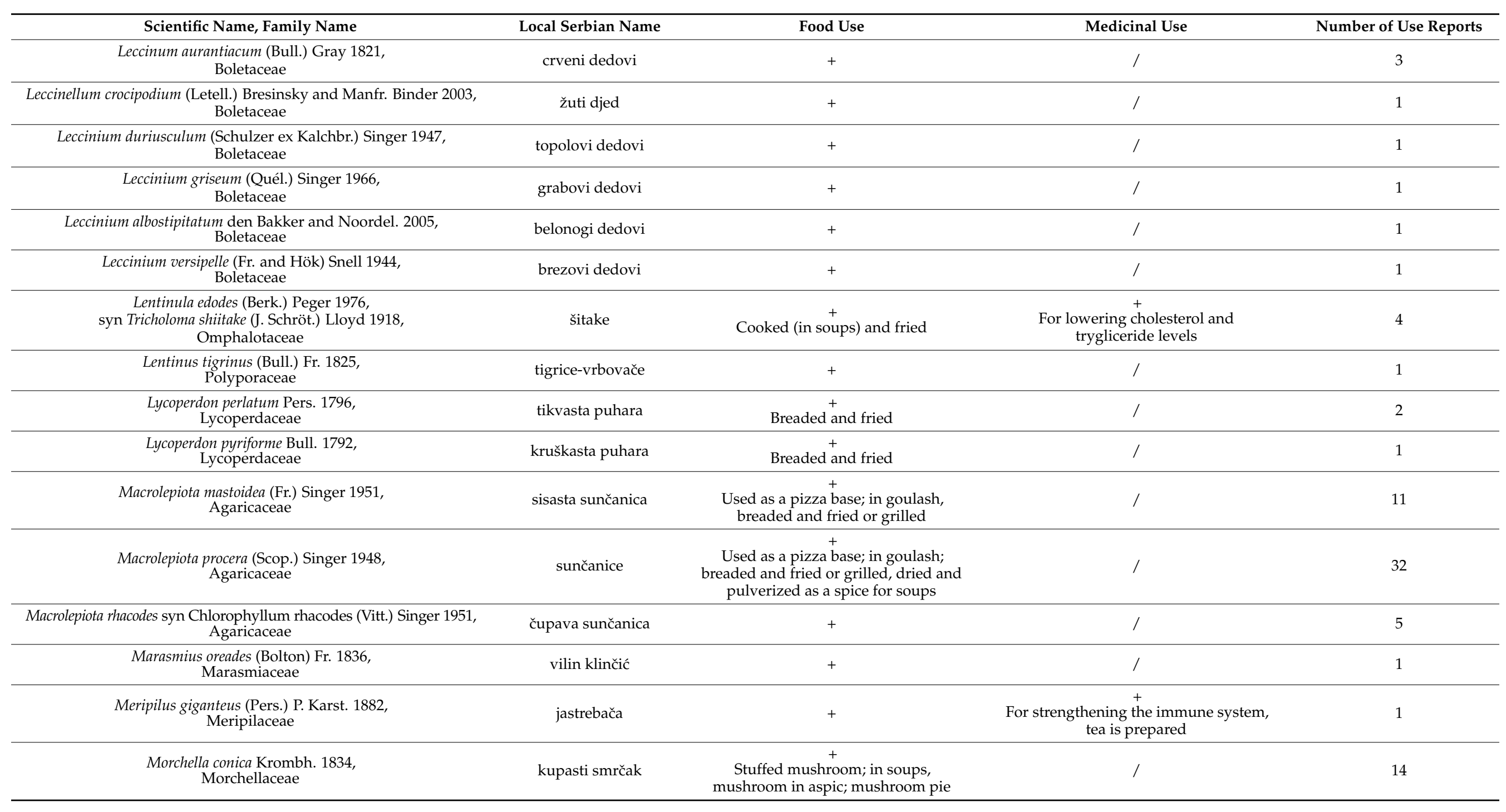


Table 2. Cont.

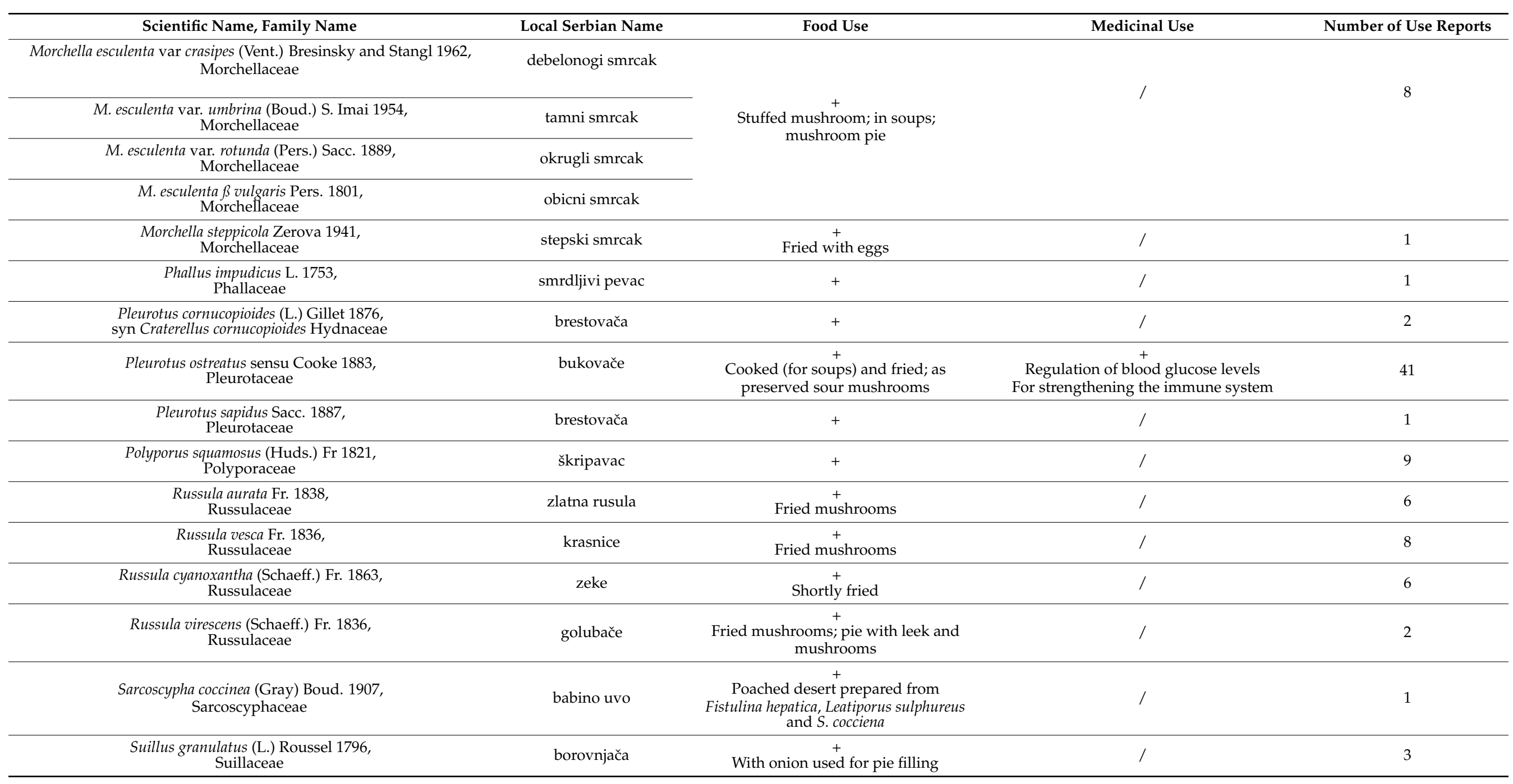


Table 2. Cont.

Scientific Name, Family Name

Local Serbian Name ćuranov rep

\section{Food Use}

Medicinal Use

For strengthening the immune system

- tea (mushroom should be soaked in

cold water and cooked for $30 \mathrm{~min}$; or
soaked in boiled water and left to stand

in it for $15 \mathrm{~min}$ )

tincture (mushrooms should be soaked

in ethanol for two weeks)
Number of Use Reports

\begin{tabular}{|c|c|c|c|c|}
\hline $\begin{array}{c}\text { Tricholoma terreum (Schaeff.) P. Kumm. 1871, } \\
\text { Tricholomataceae }\end{array}$ & miška & $\begin{array}{c}+ \\
\text { Eaten 1-2 times per year, not more } \\
\text { than } 200 \mathrm{~g} \text {. Mushroom should be } \\
\text { boiled in water, and after the removal } \\
\text { of water it can be used for omelet } \\
\text { preparation; used for mushroom pie }\end{array}$ & / & 1 \\
\hline $\begin{array}{l}\text { Tuber aestivum Vittad. 1831, } \\
\text { Tuberaceae }\end{array}$ & letnji tartuf & + & / & 1 \\
\hline $\begin{array}{l}\text { Tuber melanosporum Vittad. 1831, } \\
\text { Tuberaceae }\end{array}$ & crni tartuf & + & / & 3 \\
\hline $\begin{array}{l}\text { Tuber macrosporum Vittad. 1831, } \\
\text { Tuberaceae }\end{array}$ & tartuf & + & / & 2 \\
\hline $\begin{array}{l}\text { Tuber brumale Vittad. 1831, } \\
\text { Tuberaceae }\end{array}$ & zimski tartuf & + & / & 1 \\
\hline $\begin{array}{c}\text { Xerocomus chrysenteron (Bull.) Quél. 1888, } \\
\text { Boletaceae }\end{array}$ & zlatača & + & / & 2 \\
\hline $\begin{array}{c}\text { Xerocomus subtomentosus L. } 1753 \\
\text { syn Boletus subtomentosus, Boletaceae }\end{array}$ & velika podstavka & + & / & 2 \\
\hline $\begin{array}{l}\text { Verpa bohemica (Krombh.) J. Schrot. 1893, } \\
\text { Morchellaceae }\end{array}$ & češka smrčkovica & $\begin{array}{l}\text { As an additional ingredient for the } \\
\text { preparation of dishes due to its } \\
\text { calamari-like taste. During boiling, the } \\
\text { evaporations should not be inhaled, } \\
\text { and water should be removed } \\
\text { after cooking. }\end{array}$ & / & 1 \\
\hline
\end{tabular}


With the exception of Fomes fomentarius, Ganoderma applantatum, G. atkinsonii and G. lucidum, the reported fungus species were pointed out as edible, but only 15 of them were declared as medicinal. In Serbia, fungi are commonly utilized as prominent components of traditional foods and recipes (Figure 2). According to the literature [21], they are beneficial due to their high-quality protein, fiber, mineral and vitamin contents. Moreover, their low fat content, with a high proportion of polyunsaturated fatty acids, turns them into a source of favorable fat [22]. As stated by participants, there are several methods of preparation of edible fungi. They mainly require preparation before consumption, and usually all parts of the fruiting body are used. They mentioned that fungi are consumed cooked or fried, especially during fasting, when they are consumed as a substitute for meat. In addition, it was reported that two poisonous fungi have been used in nutrition (Tricholoma terreum and Verpa bohemica). Namely, they are used cooked, although the water in which they were boiled should be removed after processing. The reason for this is the possible presence of thermolabile toxins.

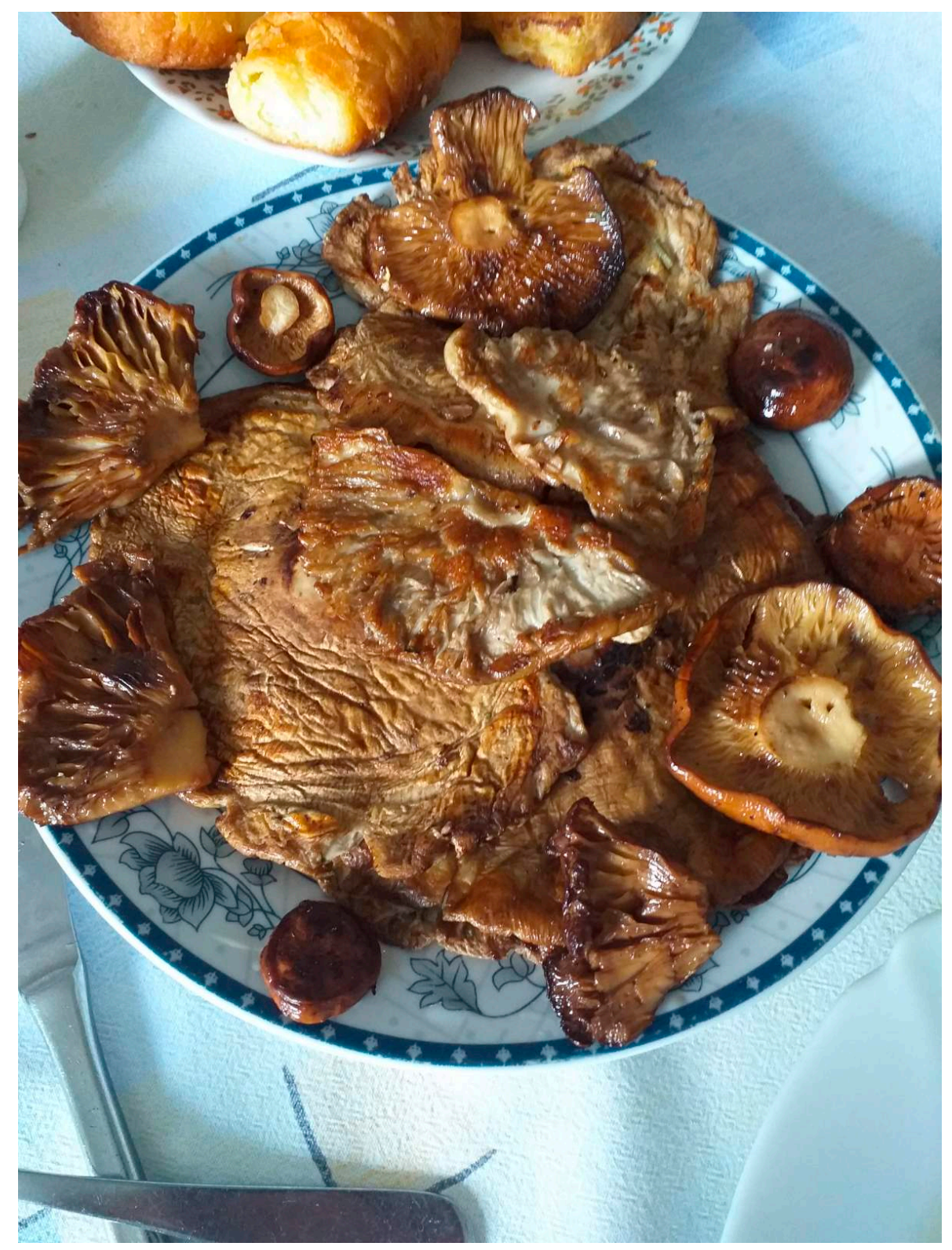

Figure 2. Grilled Macrolepiota procera and Lactarius volemus prepared by informants during the investigation. 
Today, it is not unusual for urban people, particularly from the middle class, to collect fungi for their own consumption. Furthermore, the commercial harvesting of wild edible fungi also occurs [5]. According to our survey, almost all of the participants (84\%) collected edible fungi for their households. In Serbia, both commercial and personal collections of wild mushrooms do not represent a current threat to fungal biodiversity [23]. In fact, there are much greater risks to fungal biodiversity, particularly air pollution and the use of fertilizers and pesticides.

Ethnomedicinal applications are one of the most important features of fungi, meaning that they are of nutraceutical value. Nowadays, numerous dietary supplements, in the form of extracts, tinctures and capsules, are made from medicinal fungi [24]. These are utilized for the treatment of various health conditions, including modern lifestyle diseases, as well as for their prevention. Regardless of the longstanding tradition of the utilization mushroom preparations in the therapy of human diseases, scientific confirmations of the effects of these preparations are meagre and are limited to a small number of species [25]. Namely, some of these mushrooms compounds were used in clinical trials and the obtained results provided supporting data for their medicinal applications [21]. Generally, studies dealing with mushrooms as therapeutic agents are focused mainly on in vitro data.

In our study, about $30 \%$ of the participants confirmed that they used fungi as medicine, whereas 15 fungal species ( $18 \%$ of all recorded species) were utilized due to their positive effects on health. In the following, we evaluate the status of scientific research and application for each of these species. Most of these species were consumed internally $(90 \%)$, whereas only one species (Calvatia gigantea) was utilized both internally and externally.

\subsection{Auricularia auricula-judae (Bull.) Quél}

According to Gründemann et al. [26], the use of this mushroom in European ethnomedicine has a very long tradition, and it is gargled with for the treatment of sore throats, as well as sore eyes and jaundice and as an astringent. The mushroom is also highly appreciated throughout the Asian continent. It is also known as "tree jellyfish", "wood ear" or "black mushroom", and it has long tradition of use both as food and medicine. Some data indicate that it has potential in treating throat-related ailments, as well as thrombosis deterrence. Furthermore, it is a valuable source of bioactive glucans and essential amino acids and has a fair amount of minerals $(\mathrm{Ca}, \mathrm{K}, \mathrm{Mg}, \mathrm{Fe}, \mathrm{Zn})$ which are irreplaceable in the human diet [27].

The traditional use of this mushroom as an agent in blood vessel purification (Table 1) may have recently found its scientific support. According to Bian et al. [28], fruiting bodies of mushroom are a source of acidic polysaccharides with glucuronide (defined as aAAP-1), which exhibited anticoagulant activity. As confirmed by Yoon et al. [29], polysaccharides from this mushroom are those with anticoagulant activity due to catalysis of thrombin inhibition by antithrombin, with glucuronic acid being the essential factor for this polysaccharide activity.

\subsection{Boletus edulis Bull}

Boletus edulis, also known as the king bolete, is widely consumed throughout Europe, North America and Asia. It is especially appreciated due to its flavor-a mixture of nutty, earthy and meaty. The most abundant bioactive constituents of this mushroom are antioxidants such as ascorbic acid; tocopherols, including $\alpha$-tocopherol, $\gamma$-tocopherol and $\delta$-tocopherol; and phenolic acids [30].

Various fractions/molecules present in B. edulis may be the carriers of its observed immunomodulatory capacity (Table 2). The study by Lemieszek et al. [31] has linked the immunomodulatory activity of B. edulis to its RNA fraction. This fraction was able to stimulate NK92, a natural killer cell line, inducing their proliferation and cytotoxic potential towards tumor cells. B. edulis is also highlighted as a rich source of B3 vitamin [32], a molecule that stimulates the immune response against pathogenic bacteria [33]. Among the most abundant $B$. edulis constituents are phenolic compounds, including p-coumaric 
acid [34]; due to its antioxidant capacity, this molecule has immunomodulatory properties in both physiological and pathological states [35].

\subsection{Calvatia gigantea (Batsch)}

Calvatia gigantea, or giant puffball, is considered the largest among edible mushrooms and is a promising source of compounds with medicinal activity for health foods and food supplementary products [36]. In Europe these mushrooms have been traditionally used as a powder due to their hemostatic properties, as wound dressings, as well as in the treatment of inflammation [26].

In vitro studies provide evidence for the ethnopharmacological use of $C$. gigantea for the treatment of cancer (Table 2). Calvacin, a protein obtained from the spores of this fungus, was active against a range of tumors studied by Roland et al. [37]. It has been shown that this mushroom could have beneficial effects on lung cancer-the mechanism behind this cytotoxic activity is increased Bax, p53, caspase- 3 and caspase- 9 expression, and the downregulation of G1/S-specific cyclin D1 (CCND1), CCND2, CDK4, Akt and Bcl-2 in A549 lung cancer cells [38]. One of the most abundant molecules of C. gigantea is gentisic acid [36], a phenolic compound which reduces the number of HT29 cells (human colorectal adenocarcinoma cell line) [39]. On the other hand, its most abundant sugar compound, trehalose [36], inhibited cell proliferation in two melanoma cell lines (A375 and SK-Mel-28) [40]. There are records even from few hundred years ago regarding the ability of this fungus to prevent bleeding from wounds [41]. Calvacin gel, composed of Calvatia gigantea (spore) and Gentiana macrophylla (herb), increases levels of VEGF and TGF $\beta 1$ in rats, leading to wound healing [42], altogether giving scientific support to the observed usage of C. gigantea among the Serbian population (Table 2).

\subsection{Cantharellus cibarius Fr}

Cantharellus cibarius, or gold chanterelles, is among the most frequently consumed forest mushrooms in Europe due to its apricot scent and its enticing yellow or orange color [43].

Cantharellus cibarius usage as a disease prevention agent among Serbian inhabitants (Table 1) could be linked to its abundant bioactive molecules. The agents with antiproliferative/cytotoxic properties obtained from this mushroom are numerous and include small RNAs [44], galactan [45] and branched mannans [46]. Polysaccharides from C. cibarius exhibit anti-inflammatory effects by inhibiting COX-1 and COX-2 activity [47], whereas 3-Omethylated galactan activates macrophages [48]. Polysaccharides have also displayed beneficial effects as neuroprotection agents [49]. Cantharellus cibarius, in a study by Kala et al. [50], was the richest source of lovastatin among all the mushrooms, indicating its potential application in the prevention of hypercholesterolemia.

\subsection{Coprinus comatus (O.F.Müll.) Pers}

Coprinus comatus-shaggy ink cap, lawyer's wig or shaggy mane-is an edible mushroom found and cultivated worldwide, and is a rich source of nutritional and bioactive compounds [51].

The anti-diabetic potential of $C$. comatus was confirmed through in vitro experiments (Table 2). A study by Stojković et al. [52] highlighted the methanol extract of this species as the most active one in the inhibition of enzymes linked to type-2 diabetes, especially $\alpha$-amylase. Comatin, a chemical isolated from Coprinus comatus fermentation broth, exhibited hypoglycemic effects in both normal and alloxan-induced-diabetic rats in a study by Ding et al. [53]. Polysaccharide fractions obtained from this mushroom have also been shown to reduce blood glucose concentrations in $120 \mathrm{~min}$ and have a long-term hypoglycemic effect, possibly linked to immune stimulation [54]. 


\subsection{Cyclocybe aegerita (V. Brig.) Vizzini}

Cyclocybe aegerita, known as black poplar mushroom or chestnut mushroom, is cultivated in countries such as Italy due to its pleasant taste. It is rich in carbohydrates, ash and proteins [55].

The recorded usage of $C$. aegerita as a disease preventive agent (Table 1) is strongly supported by the range of bioactivities recorded for this mushroom extract and/or single compounds. Cyclocybe aegerita bioactive properties include a strong antioxident potential [55], that might be linked to the presence of antioxidant peptides [55] and polysaccharides [56]. Its antimicrobial and anti-quorum sensing traits [57] suggest its ability to be applied as infection-preventive agent. Some of $C$. aegerita's bioactive components are galectin, with anti-metastatic activity [58]; ageritin, which displays antimicrobial as well as antiproliferative properties [59]; and serine proteases, which could serve as anticoagulant and antithrombolytic agents [60].

\subsection{Fomitopsis betulina (Bull.) B.K.Cui, M.L.Han and Y.C.Dai}

Fomitopsis betulina, birch polypore, is a wood-rotting medicinal and edible (when young) mushroom. It has been commonly applied in the folk medicine of Russia, Poland and other Baltic countries, primarily as an antiparasitic and antimicrobial agent and to stop wound bleeding. For these purposes, it is used orally as a tea or snuffed as a powder or ash [26]. In addition, it has been traditionally used for a range of diseases such as cancers [61]. Its use as a tea for enhancing immunity was previously recorded for F. betulina in Russia [61]. However, when its immunomodulating activity was evaluated in vitro by Shamtsyan et al. [62], this species did not exhibit a strong effect as compared to other evaluated Basidiomycetes. Further scientific studies should be conducted to provide evidence or rebut the traditional usage of F. betulina as an immune booster.

\subsection{Ganoderma applanatum (Pers.) Pat}

Ganoderma applanatum, artist's bracket, is found throughout the world, mainly on the bases of tree stumps. It has been used in Chinese herbal medicine, along with G. lucidum, in order to treat or prevent a range of chronic diseases [63].

The exo-biopolymer from this fungus, mainly containing carbohydrates, is able to increase the activity of natural killer cells [64]. Polysaccharides from G. applanatum were able to regenerate NK cell activity and the IL2 and IFN $\gamma$ production of the spleen cells in sarcoma 180 transplanted mice [65], altogether giving support for its observed traditional usage in the Serbian population (Table 2).

\subsection{Ganoderma atkinsonii Jahn, Kotl. and Pouz}

Ganoderma atkinsonii is found in Europe and in the Euro-Asian region. Some records [66] indicate its promising antioxidant potential due to the presence of bioactive molecules such as 2,5-dihydroxybenzoic acid and vanillic acid. Vanillic acid is also proven to have an immunomodulatory effect through peripheral blood mononuclear cell (PBMC) stimulation and IFN- $\gamma$ secretion [67], so this might be one of the components responsible for its bioactivities.

\subsection{Ganoderma lucidum (Curtis) P. Karst}

Ganoderma lucidum is one of the most widely recognized medicinal mushrooms. Some of the indications for its usage are bronchitis, asthma, hypercholesterolemia, hepatopathy, hypertension, arthritis, neurasthenia, hypertension and immunological diseases, all due to numerous bioactive molecules present in this fungus-phenolic compounds, polysaccharides and terpenes [68].

Extracts from this fungus regulated the expression levels of serum immune cytokines and enhanced the anti-tumor immunostimulatory activity in a Hepa1-6-bearing C57 BL/6 mouse model [69]. The mycelium of G. lucidum stimulates innate immunity through the activation of NF-kappaB [70] and various studies have shown that G. lucidum can act on different components of immune defense, including antigen-presenting cells, NK cells and 
T and B lymphocytes [71]. Even a randomized, double-blind and placebo-controlled study in children with cancer confirmed the immunomodulatory potential of G. lucidum [72], highlighting it as a promising immune enhancer, as was observed in Serbian population (Table 2).

A bioactive mixture containing G. lucidum described by Lu et al. [73] exhibited great potential in oral cancer treatment. It induced cell apoptosis and inhibited migration as well as cyclin expression, and also significantly reduced tumor growth in mice. On the other hand, its observed usage in the control of high blood pressure (Table 2) was not supported by evidence from a double-blind, randomized, placebo-controlled trial conducted by Klupp et al. [74]. This study does not suggest the use of G. lucidum for the treatment of cardiovascular risk factors in people with diabetes mellitus or metabolic syndrome.

\subsection{Lentinula edodes (Berk.) Peger}

Lentnula edodes, shiitake mushroom, has been cultivated throughout Asia for many years, and according to traditional Chinese medicine it exhibits beneficial effects on heart health, lung diseases and many other indications. The spectrum of its biological activities is associated with its nutritional profile and the presence of biologically active molecules such as dietary fiber; provitamin D2; and vitamins B1, B2, B12 and niacin [75].

Its role in the prevention of high cholesterol blood levels (Table 2) could be attributed to the presence of lovastatin, a cholesterol-lowering drug, in its fruiting bodies [50] and the hypocholesterolemic molecule eritadenine [76]. Furthermore, a $\beta$-glucan-enriched extract of this mushroom was able to profoundly reduce the levels of cholesterol in a mouse model [77]. Previously, it has been shown that the intake of shiitake mushroom by male Wistar rats significantly reduced cholesterol concentrations in the blood [78].

\subsection{Meripilus giganteus (Pers.) P. Karst}

Meripilus giganteus is a tree parasite with an edible fruiting body. It is rich in carbohydrates and proteins, whereas it presents a low fat content [79].

The immunity enhancing activity recorded in this study for M. giganteus (Table 1) has not been experimentally confirmed to date. This recorded activity might be linked to the presence of chemical constituents [79] with confirmed immunomodulatory activity, including cinnamic [80] and p-coumaric acids [35].

\subsection{Pleurotus ostreatus Sensu Cooke}

Pleurotus ostreatus, oyster mushroom, is the second most cultivated edible mushroom worldwide, after Agaricus bisporus. It is rich in $\beta$-glucans and dietary fibers, with a range of biological roles [81].

Clinical trials have demonstrated the beneficial effects of $P$. ostreatus intake on glucose metabolism, mainly the reduction in fasting and/or $2 \mathrm{~h}$ postprandial glucose [81], giving support for its use in diabetes indications (Table 2). A diet enriched with Agaricus bisponus and Pleurotus ostreatus eliminated the negative effects of diabetes in experimental animals by reducing the serum glucose level after 28 days of application [82]. The anti-diabetic and anti-hyperglycemic effects of P. ostreatus were linked to molecules such as ergosterol [83] and polysaccharides [84].

P. ostreatus has been used among the studied population in order to enhance immunity (Table 2). In previous studies, food supplementation with $P$. ostreatus increased levels of interleukin-2, immunoglobulin $\mathrm{G}$ and immunoglobulin $\mathrm{M}$; tumor necrosis factor- $\alpha$; as well as immunoglobulin A in piglets [85]. The addition of aqueous extracts of P. ostreatus to the diet of malnourished mice enhanced their humoral immunity and activated macrophage cells [86]. The immunomodulatory effect of oyster mushrooms could be attributed to the prescence of lectin [87] and pleuran- $\beta$-glucan [88]. 


\subsection{Trametes versicolor (L.) Lloyd}

Trametes versicolor, turkey tail, is a medicinal mushroom that is widely used due to its medicinal value, with characteristic morphological features-concentric multicolored zones on the upper side of the cap [89].

Polysaccharopeptides from $T$. versicolor modulate immunity by reducing levels of TLR4, MyD88, CD14, IL-1 $\beta$ and TNF- $\alpha$ expression [90], whereas polysaccharides bind and activate B cells [91]. Glucan from this mushroom exhibits immunomodulatory activity by increasing the secretion of various interleukins and interferons [92], and $\beta$-glucans from T. versicolor can also protect mice from Salmonella typhimurium infection by enhancing the activity of innate immune cells [93]. The current knowledge on the immunomodulatory effects of $C$. versicolor and its components has been reviewed by Chu et al. [94], Saleh et al. [95] and Habtemariam [89], and these studies provide strong support for its traditional usage in the Serbian population (Table 2).

\section{Conclusions}

The Balkan Peninsula, which is very rich in mushroom genetic resources, deserves more intensive ethnomycological studies. The current study provides useful documentation, which can contribute to preserving ethnomycological knowledge in Serbia. Interest in mycology is on the rise, as evidenced by the high number of species used by amateur mycologists. This interest contributes to the development of more detailed knowledge on mycomedicinces and mycofood. There is a need for further ethnomycological studies in order to preserve the current knowledge, since the use of fungi as food and medicine was mainly recorded among the elderly population.

Author Contributions: Conceptualization, J.Ž. and D.S.; methodology, J.G.; validation, J.G. and D.S.; formal analysis, J.Ž. and J.G.; data curation, J.Ž. and M.I.; writing-original draft preparation, J.Ž. and M.I.; writing-review and editing, D.S. and J.G.; supervision, J.G. All authors have read and agreed to the published version of the manuscript.

Funding: This work has been supported by Ministry of Education, Science and Technological Development of Republic of Serbia (451-03-9/2021-14/200007 and 451-03-9/2021-14/200003).

Institutional Review Board Statement: Not applicable.

Informed Consent Statement: Informed consent was obtained from all subjects involved in the study.

Data Availability Statement: The data presented in this study are available on request from the first author.

Acknowledgments: The authors are grateful for the kind cooperation of the Mycological Society of Serbia, Mycological Society of Novi Sad, Ecological Society Studenac, Mushroom Society Šumadija, Mushroom Society Požarevac and the Association of Mushroom and Nature Lovers Vilino kolo.

Conflicts of Interest: The authors declare no conflict of interest.

\section{References}

1. Reyes-López, R.C.; Montoya, A.; Kong, A.; Cruz-Campuzano, E.A.; Caballero-Nieto, J. Folk classification of wild mushrooms from San Isidro Buensuceso, Tlaxcala, Central Mexico. J. Ethnobiol. Ethnomed. 2020, 16, 53. [CrossRef]

2. Brown, M. Yi Ethnomycology: Wild Mushroom Knowledge and Use in Yunnan, China. J. Ethnobiol. 2019, 39, 131. [CrossRef]

3. Yilmaz, H.; Zencirci, N. Ethnomycology of Macrofungi in the Western Black Sea Region of Turkey: Identification to Marketing. Econ. Bot. 2016, 70, 270-284. [CrossRef]

4. Senn-Irlet, B.; Heilmann-Clausen, J.; Genney, D.; Dahlberg, A. Guidance for Conservation of Macrofungi in Europe; The Directorate of Culture and Cultural and Natural Heritage Council of Europe: Strasbourg, France, 2007.

5. Svanberg, I.; Lindh, H. Mushroom hunting and consumption in twenty-first century post-industrial Sweden. J. Ethnobiol. Ethnomed. 2019, 15, 42. [CrossRef] [PubMed]

6. Soković, M.; Glamočlija, J.; Ćirić, A.; Petrović, J.; Stojković, D. Mushrooms as Sources of Therapeutic Foods. In Therapeutic Foods; Elsevier: Amsterdam, The Netherlands, 2018; pp. 141-178. 
7. Robles-García, D.; Suzán-Azpiri, H.; Montoya-Esquivel, A.; García-Jiménez, J.; Esquivel-Naranjo, E.U.; Yahia, E.; Landeros-Jaime, F. Ethnomycological knowledge in three communities in Amealco, Quéretaro, México. J. Ethnobiol. Ethnomed. 2018, 14, 1-13. [CrossRef] [PubMed]

8. Živković, J.; Ilić, M.; Šavikin, K.; Zdunić, G.; Ilić, A.; Stojković, D. Traditional Use of Medicinal Plants in South-Eastern Serbia (Pčinja District): Ethnopharmacological Investigation on the Current Status and Comparison with Half a Century Old Data. Front. Pharmacol. 2020, 11, 1020. [CrossRef] [PubMed]

9. Bernicchia, A. Fungi Europaei; Candusso Editions: Alassio, Italy, 2005; p. 808.

10. Flik, M. Koja je Ovo Gljiva? Alba Graeca Book: Belgrade, Serbia, 2010.

11. Hadžić, I.; Vukojević, J. Atlas Gljiva i Internacionalni Rečnik Narodnih Imena Gljiva; Univerzitet u Beogradu, Biološki Fakultet: Belgrade, Serbia, 2013.

12. Hobbs, C. Medicinal Mushrooms: An Exploration of Tradition, Healing and Culture; Botanica Press: Santa Cruz, CA, USA, 1995.

13. Knudsen, H.; Vesterholt, J. Agaricoid, Boletoid and Cyphelloid Genera; Funga Nordica: Nordsvamp, Copenhagen, 2008.

14. Lǽssǿe, T.; Petersen, J.H. Fungi of Temperate Europe, 1st ed.; Princeton University Press: Princeton, NJ, USA, 2019.

15. Moser, M. Keys to Agarics and Boleti; Mad River Pr. Inc.: Eureka, CA, USA, 1983.

16. Polese, J.M. The Pocket Guide to Mushrooms; Könemann: New York, NJ, USA, 2000.

17. Sarnari, M. Monografia Illustrata del Genere Russula in Europa, 1st ed.; AMB, Centro Studi Micologici: Trento, Italy, 1998.

18. Sarnari, M. Monografia Illustrata del Genere Russula in Europa, 2nd ed.; AMB, Centro Studi Micologici: Trento, Italy, 2005.

19. Singer, R. The Agaricales in Modern Taxonomy; Koeltz Scientific: Koenigstein, Germany, 1986.

20. Phillips, R. Mushrooms; Macmillan Publishers Limited: New York, NY, USA, 2006.

21. Soković, M.; Ćirić, A.; Glamočlija, J.; Stojković, D. The Bioactive Properties of Mushrooms. In Wild Plants, Mushrooms and Nuts: Functional Food Properties and Applications; Wiley: Chichester, UK, 2016; pp. 83-122. ISBN 9781118944653.

22. Sitotaw, R.; Lulekal, E.; Abate, D. Ethnomycological study of edible and medicinal mushrooms in Menge District, Asossa Zone, Benshangul Gumuz Region, Ethiopia. J. Ethnobiol. Ethnomed. 2020, 16, 11. [CrossRef]

23. Radomir, M.; Mesud, A.; Žaklina, M. Conservation and trade of wild edible mushrooms of Serbia-History, state of the art and perspectives. Nat. Conserv. 2018, 25, 31-53. [CrossRef]

24. Comandini, O.; Rinaldi, A.C. Ethnomycology in Europe: The past, the present, and the future. In Mushrooms, Humans and Nature in a Changing World: Perspectives from Ecological, Agricultural and Social Sciences; Springer International Publishing: New York, NY, USA, 2020; pp. 341-364, ISBN 9783030373788.

25. Money, N.P. Are mushrooms medicinal? Fungal Biol. 2016, 120, 449-453. [CrossRef]

26. Gründemann, C.; Reinhardt, J.K.; Lindequist, U. European medicinal mushrooms: Do they have potential for modern medicine?An update. Phytomedicine 2020, 66, 153131. [CrossRef]

27. Kadnikova, I.A.; Costa, R.; Kalenik, T.K.; Guruleva, O.N.; Yanguo, S. Chemical Composition and Nutritional Value of the Mushroom Auricularia auricula-judae. J. Food Nutr. Res. 2015, 3, 478-482. [CrossRef]

28. Bian, C.; Wang, Z.; Shi, J. Extraction Optimization, Structural Characterization, and Anticoagulant Activity of Acidic Polysaccharides from Auricularia auricula-judae. Molecules 2020, 25, 710. [CrossRef] [PubMed]

29. Yoon, S.J.; Yu, M.A.; Pyun, Y.R.; Hwang, J.K.; Chu, D.C.; Juneja, L.R.; Mourão, P.A.S. The nontoxic mushroom Auricularia auricula contains a polysaccharide with anticoagulant activity mediated by antithrombin. Thromb. Res. 2003, 112, 151-158. [CrossRef] [PubMed]

30. Barros, L.; Barreira, J.C.M.; Grangeia, C.; Batista, C.; Cadavez, V.A.P.; Ferreira, I.C.F.R. Beef burger patties incorporated with Boletus edulis extracts: Lipid peroxidation inhibition effects. Eur. J. Lipid Sci. Technol. 2011, 113, 737-743. [CrossRef]

31. Lemieszek, M.K.; Nunes, F.H.F.M.; Sawa-Wejksza, K.; Rzeski, W. A king bolete, Boletus edulis (Agaricomycetes), RNA fraction stimulates proliferation and cytotoxicity of natural killer cells against myelogenous leukemia cells. Int. J. Med. Mushrooms 2017, 19, 347-353. [CrossRef] [PubMed]

32. Jaworska, G.; Pogoń, K.; Skrzypczak, A.; Bernaś, E. Composition and antioxidant properties of wild mushrooms Boletus edulis and Xerocomus badius prepared for consumption. J. Food Sci. Technol. 2015, 52, 7944-7953. [CrossRef]

33. Kyme, P.; Thoennissen, N.H.; Tseng, C.W.; Thoennissen, G.B.; Wolf, A.J.; Shimada, K.; Krug, U.O.; Lee, K.; Müller-Tidow, C.; Berdel, W.E.; et al. C/EBP $\varepsilon$ mediates nicotinamide-enhanced clearance of Staphylococcus aureus in mice. J. Clin. Investig. 2012, 122, 3316-3329. [CrossRef]

34. Heleno, S.A.; Ferreira, R.C.; Antonio, A.L.; Queiroz, M.J.R.P.; Barros, L.; Ferreira, I.C.F.R. Nutritional value, bioactive compounds and antioxidant properties of three edible mushrooms from Poland. Food Biosci. 2015, 11, 48-55. [CrossRef]

35. Kilani-Jaziri, S.; Mokdad-Bzeouich, I.; Krifa, M.; Nasr, N.; Ghedira, K.; Chekir-Ghedira, L. Immunomodulatory and cellular anti-oxidant activities of caffeic, ferulic, and p-coumaric phenolic acids: A structure-activity relationship study. Drug Chem. Toxicol. 2017, 40, 416-424. [CrossRef]

36. Kıvrak, İ.; Kıvrak, Ş.; Harmandar, M. Bioactive compounds, chemical composition, and medicinal value of the giant puffball, calvatia gigantea (Higher Basidiomycetes), from Turkey. Int. J. Med. Mushrooms 2016, 18, 97-107. [CrossRef] [PubMed]

37. Roland, J.F.; Chmielewicz, Z.F.; Weiner, B.A.; Gross, A.M.; Boening, O.P.; Luck, J.V.; Bardos, T.J.; Reilly, H.C.; Sugiura, K.; Stock, C.C.; et al. Calvacin: A new antitumor agent. Science 1960, 132, 1897. [CrossRef] [PubMed]

38. Eroğlu, C.; Seçme, M.; Atmaca, P.; Kaygusuz, O.; Gezer, K.; Bağcl, G.; Dodurga, Y. Extract of Calvatia gigantea inhibits proliferation of A549 human lung cancer cells. Cytotechnology 2016, 68, 2075-2081. [CrossRef] [PubMed] 
39. Michalak, M.; Szwajgier, D.; Paduch, R.; Kukula-Koch, W.; Waśko, A.; Polak-Berecka, M. Fermented curly kale as a new source of gentisic and salicylic acids with antitumor potential. J. Funct. Foods 2020, 67, 103866. [CrossRef]

40. Allavena, G.; Del Bello, B.; Tini, P.; Volpi, N.; Valacchi, G.; Miracco, C.; Pirtoli, L.; Maellaro, E. Trehalose inhibits cell proliferation and amplifies long-term temozolomide- and radiation-induced cytotoxicity in melanoma cells: A role for autophagy and premature senescence. J. Cell. Physiol. 2019, 234, 11708-11721. [CrossRef] [PubMed]

41. Berkeley, M.J. Introduction to Cryptogamic Botany; H. Bailliere: London, UK, 1857.

42. Buyantogtokh, D.; Chuluunbaatar, E.; Tsogzol, M.; Uranbileg, N.; Chimedtseren, C.; Dagvatseren, B. Wound healing effects of calvacin gel on burn wound in rats. Biomed. Pharmacol. J. 2020, 13, 701-709. [CrossRef]

43. Nowakowski, P.; Markiewicz-Żukowska, R.; Gromkowska-Kępka, K.; Naliwajko, S.K.; Moskwa, J.; Bielecka, J.; Grabia, M.; Borawska, M.; Socha, K. Mushrooms as potential therapeutic agents in the treatment of cancer: Evaluation of anti-glioma effects of Coprinus comatus, Cantharellus cibarius, Lycoperdon perlatum and Lactarius deliciosus extracts. Biomed. Pharmacol. 2021, 133, 111090. [CrossRef]

44. Lemieszek, M.K.; Marques, P.S.; Ribeiro, M.; Ferreira, D.; Marques, G.; Chaves, R.; Pozarowski, P.; Nunes, F.M.; Rzeski, W. Mushroom small RNAs as potential anticancer agents: A closer look at: Cantharellus cibarius proapoptotic and antiproliferative effects in colon cancer cells. Food Funct. 2019, 10, 2739-2751. [CrossRef]

45. Meng, Y.; Qu, Y.; Wu, W.; Chen, L.; Sun, L.; Tai, G.; Zhou, Y.; Cheng, H. Galactan isolated from Cantharellus cibarius modulates antitumor immune response by converting tumor-associated macrophages toward M1-like phenotype. Carbohydr. Polym. 2019, 226, 115295. [CrossRef] [PubMed]

46. Lemieszek, M.K.; Nunes, F.M.; Rzeski, W. Branched mannans from the mushroom: Cantharellus cibarius enhance the anticancer activity of natural killer cells against human cancers of lung and colon. Food Funct. 2019, 10, 5816-5826. [CrossRef]

47. Nowacka-Jechalke, N.; Nowak, R.; Juda, M.; Malm, A.; Lemieszek, M.; Rzeski, W.; Kaczyński, Z. New biological activity of the polysaccharide fraction from Cantharellus cibarius and its structural characterization. Food Chem. 2018, 268, 355-361. [CrossRef]

48. Yang, G.; Qu, Y.; Meng, Y.; Wang, Y.; Song, C.; Cheng, H.; Li, X.; Sun, L.; Zhou, Y. A novel linear 3-O-methylated galactan isolated from Cantharellus cibarius activates macrophages. Carbohydr. Polym. 2019, 214, 34-43. [CrossRef] [PubMed]

49. Lemieszek, M.K.; Nunes, F.M.; Cardoso, C.; Marques, G.; Rzeski, W. Neuroprotective properties of Cantharellus cibarius polysaccharide fractions in different in vitro models of neurodegeneration. Carbohydr. Polym. 2018, 197, 598-607. [CrossRef]

50. Kała, K.; Kryczyk-Poprawa, A.; Rzewińska, A.; Muszyńska, B. Fruiting bodies of selected edible mushrooms as a potential source of lovastatin. Eur. Food Res. Technol. 2020, 246, 713-722. [CrossRef]

51. Stojković, D.; Reis, F.S.; Barros, L.; Glamočlija, J.; Ćirić, A.; van Griensven, L.J.I.D.; Soković, M.; Ferreira, I.C.F.R. Nutrients and non-nutrients composition and bioactivity of wild and cultivated Coprinus comatus (O.F.Müll.) Pers. Food Chem. Toxicol. 2013, 59, 289-296. [CrossRef] [PubMed]

52. Stojkovic, D.; Smiljkovic, M.; Ciric, A.; Glamoclija, J.; Van Griensven, L.; Ferreira, I.C.F.R.; Sokovic, M. An insight into antidiabetic properties of six medicinal and edible mushrooms: Inhibition of $\alpha$-amylase and $\alpha$-glucosidase linked to type- 2 diabetes. South Afr. J. Bot. 2019, 120, 100-103. [CrossRef]

53. Ding, Z.; Lu, Y.; Lu, Z.; Lv, F.; Wang, Y.; Bie, X.; Wang, F.; Zhang, K. Hypoglycaemic effect of comatin, an antidiabetic substance separated from Coprinus comatus broth, on alloxan-induced-diabetic rats. Food Chem. 2010, 121, 39-43. [CrossRef]

54. Zhou, S.; Liu, Y.; Yang, Y.; Tang, Q.; Zhang, J. Hypoglycemic activity of polysaccharide from fruiting bodies of the shaggy ink cap medicinal mushroom, coprinus comatus (Higher basidiomycetes), on mice induced by alloxan and its potential mechanism. Int. J. Med. Mushrooms 2015, 17, 957-964. [CrossRef]

55. Petrović, J.; Glamočlija, J.; Stojković, D.; Ćirić, A.; Barros, L.; Ferreira, I.C.F.R.; Soković, M. Nutritional value, chemical composition, antioxidant activity and enrichment of cream cheese with chestnut mushroom Agrocybe aegerita (Brig.) Sing. J. Food Sci. Technol. 2015, 52, 6711-6718. [CrossRef]

56. Jing, H.; Zhang, Q.; Liu, M.; Zhang, J.; Zhang, C.; Li, S.; Ren, Z.; Gao, Z.; Liu, X.; Jia, L. Polysaccharides with antioxidative and antiaging activities from enzymatic-extractable mycelium by agrocybe aegerita (Brig.) sing. Evid. Based Complement. Altern. Med. 2018, 2018. [CrossRef]

57. Petrović, J.; Glamočlija, J.; Stojković, D.; Nikolić, M.; Ćirić, A.; Fernandes, A.; Ferreira, I.C.F.R.; Soković, M. Bioactive composition, antimicrobial activities and the influence of Agrocybe aegerita (Brig.) Sing on certain quorum-sensing-regulated functions and biofilm formation by Pseudomonas aeruginosa. Food Funct. 2014, 5, 3296-3303. [CrossRef]

58. Yang, Q.; Yin, Y.; Pan, Y.; Ye, X.; Xu, B.; Yu, W.; Zeng, H.; Sun, H. Anti-metastatic activity of Agrocybe aegerita galectin (AAL) in a mouse model of breast cancer lung metastasis. J. Funct. Foods 2018, 41, 163-170. [CrossRef]

59. Citores, L.; Ragucci, S.; Ferreras, J.M.; Di Maro, A.; Iglesias, R. Ageritin, a Ribotoxin from Poplar Mushroom (Agrocybe aegerita) with Defensive and Antiproliferative Activities. ACS Chem. Biol. 2019, 14, 1319-1327. [CrossRef]

60. Li, G.; Liu, X.; Cong, S.; Deng, Y.; Zheng, X. A novel serine protease with anticoagulant and fibrinolytic activities from the fruiting bodies of mushroom Agrocybe aegerita. Int. J. Biol. Macromol. 2021, 168, 631-639. [CrossRef] [PubMed]

61. Grienke, U.; Zöll, M.; Peintner, U.; Rollinger, J.M. European medicinal polypores-A modern view on traditional uses. J. Ethnopharmacol. 2014, 154, 564-583. [CrossRef] [PubMed]

62. Shamtsyan, M.; Konusova, V.; Maksimova, Y.; Goloshchev, A.; Panchenko, A.; Simbirtsev, A.; Petrishchev, N.; Denisova, N. Immunomodulating and anti-tumor action of extracts of several mushrooms. J. Biotechnol. 2004, 113, 77-83. [CrossRef] [PubMed] 
63. Luo, Q.; Di, L.; Dai, W.F.; Lu, Q.; Yan, Y.M.; Yang, Z.L.; Li, R.T.; Cheng, Y.X. Applanatumin A, a new dimeric meroterpenoid from Ganoderma applanatum that displays potent antifibrotic activity. Org. Lett. 2015, 17, 1110-1113. [CrossRef] [PubMed]

64. Jeong, Y.T.; Yang, B.K.; Jeong, S.C.; Kim, S.M.; Song, C.H. Ganoderma applanation: A promising mushroom for antitumor and immunomodulating activity. Phyther. Res. 2008, 22, 614-619. [CrossRef]

65. Bin, G.; Gui-Zhen, Y. Effects ofGanoderma applanatum polysaccharide on cellular and humoral immunity in normal and sarcoma 180 transplanted mice. Phyther. Res. 1991, 5, 134-138. [CrossRef]

66. Yalcin, O.U.; Sarikurkcu, C.; Cengiz, M.; Gungor, H.; Ćavar Zeljković, S. Ganoderma carnosum and Ganoderma pfeifferi: Metal concentration, phenolic content, and biological activity. Mycologia 2020, 112, 1-8. [CrossRef] [PubMed]

67. Chiang, L.C.; Ng, L.T.; Chiang, W.; Chang, M.Y.; Lin, C.C. Immunomodulatory activities of flavonoids, monoterpenoids, triterpenoids, iridoid glycosides and phenolic compounds of Plantago species. Planta Med. 2003, 69, 600-604. [CrossRef]

68. Stojković, D.S.; Barros, L.; Calhelha, R.C.; Glamočlija, J.; Ćirić, A.; Van Griensven, L.J.L.D.; Soković, M.; Ferreira, I.C.F.R. A detailed comparative study between chemical and bioactive properties of Ganoderma lucidum from different origins. Int. J. Food Sci. Nutr. 2014, 65, 42-47. [CrossRef]

69. Zhao, R.; Chen, Q.; He, Y.M. The effect of Ganoderma lucidum extract on immunological function and identify its anti-tumor immunostimulatory activity based on the biological network. Sci. Rep. 2018, 8, 1-14. [CrossRef]

70. Kuo, M.C.; Weng, C.Y.; Ha, C.L.; Wu, M.J. Ganoderma lucidum mycelia enhance innate immunity by activating NF-kB. J. Ethnopharmacol. 2006, 103, 217-222. [CrossRef]

71. Lin, Z.B.; Zhang, H.N. Anti-tumor and immunoregulatory activities of Ganoderma lucidum and its possible mechanisms. Acta Pharmacol. Sin. 2004, 25, 1387-1395.

72. Shing, M.K.; Leung, T.F.; Chu, Y.L.; Li, C.Y.; Chik, K.W.; Leung, P.C.; Lee, V.; Yuen, P.M.; Li, C.K. Randomized, double-blind and placebo-controlled study of the immunomodulatory effects of Lingzhi in children with cancers. J. Clin. Oncol. 2008, 26, 14021. [CrossRef]

73. Lu, J.H.; Chou, Y.R.; Deng, Y.H.; Huang, M.S.; Chien, S.T.; Quynh, B.T.N.; Wu, C.Y.; Achtmann, E.A.P.; Cheng, H.C.; Dubey, N.K.; et al. The novel herbal cocktail aga alleviates oral cancer through inducing apoptosis, inhibited migration and promotion of cell cycle arrest at subg1 phase. Cancers 2020, 12, 3214. [CrossRef] [PubMed]

74. Klupp, N.L.; Kiat, H.; Bensoussan, A.; Steiner, G.Z.; Chang, D.H. A double-blind, randomised, placebo-controlled trial of Ganoderma lucidum for the treatment of cardiovascular risk factors of metabolic syndrome. Sci. Rep. 2016, 6, 1-10. [CrossRef]

75. Fukushima-Sakuno, E. Bioactive small secondary metabolites from the mushrooms Lentinula edodes and Flammulina velutipes. J. Antibiot. 2020, 73, 687-696. [CrossRef] [PubMed]

76. Asada, N.; Kairiku, R.; Tobo, M.; Ono, A. Effects of Shiitake Intake on Serum Lipids in Rats Fed Different High-Oil or High-Fat Diets. J. Diet. Suppl. 2019, 16, 345-356. [CrossRef] [PubMed]

77. Morales, D.; Tejedor-Calvo, E.; Jurado-Chivato, N.; Polo, G.; Tabernero, M.; Ruiz-Rodríguez, A.; Largo, C.; Soler-Rivas, C. In vitro and in vivo testing of the hypocholesterolemic activity of ergosterol- and $\beta$-glucan-enriched extracts obtained from shiitake mushrooms (Lentinula edodes). Food Funct. 2019, 10, 7325-7332. [CrossRef]

78. Spim, S.R.V.; de Oliveira, B.G.C.C.; Leite, F.G.; Gerenutti, M.; Grotto, D. Effects of Lentinula edodes consumption on biochemical, hematologic and oxidative stress parameters in rats receiving high-fat diet. Eur. J. Nutr. 2017, 56, 2255-2264. [CrossRef] [PubMed]

79. Stojković, D.S.; Kovačević-Grujičić, N.; Reis, F.S.; Davidović, S.; Barros, L.; Popović, J.; Petrović, I.; Pavić, A.; Glamočlija, J.; Ćirić, A.; et al. Chemical composition of the mushroom Meripilus giganteus Karst. and bioactive properties of its methanolic extract. LWT Food Sci. Technol. 2017, 79, 454-462. [CrossRef]

80. Conti, B.J.; Búfalo, M.C.; Golim, M.D.A.; Bankova, V.; Sforcin, J.M. Cinnamic acid is partially involved in propolis immunomodulatory action on human monocytes. Evid. Based Complement. Altern. Med. 2013, 2013. [CrossRef] [PubMed]

81. Dicks, L.; Ellinger, S. Effect of the intake of oyster mushrooms (Pleurotus ostreatus) on cardiometabolic parameters-A systematic review of clinical trials. Nutrients 2020, 12, 1134. [CrossRef] [PubMed]

82. Nweze, C.C.; Rasaq, N.O.; Istifanus, B.I. Ameliorating effect of Agaricus bisponus and Pleurotus ostreatus mixed diet on Alloxan-induced hyperglycemic rats. Sci. Afr. 2020, 7, e00209. [CrossRef]

83. Xiong, M.; Huang, Y.; Liu, Y.; Huang, M.; Song, G.; Ming, Q.; Ma, X.; Yang, J.; Deng, S.; Wen, Y.; et al. Antidiabetic Activity of Ergosterol from Pleurotus Ostreatus in KK-Ay Mice with Spontaneous Type 2 Diabetes Mellitus. Mol. Nutr. Food Res. 2018, 62, 1700444. [CrossRef]

84. Zhang, Y.; Hu, T.; Zhou, H.; Zhang, Y.; Jin, G.; Yang, Y. Antidiabetic effect of polysaccharides from Pleurotus ostreatus in streptozotocin-induced diabetic rats. Int. J. Biol. Macromol. 2016, 83, 126-132. [CrossRef]

85. Adams, S.; Che, D.; Hailong, J.; Zhao, B.; Rui, H.; Danquah, K.; Qin, G. Effects of pulverized oyster mushroom (Pleurotus ostreatus) on diarrhea incidence, growth performance, immunity, and microbial composition in piglets. J. Sci. Food Agric. 2019, 99, 3616-3627. [CrossRef] [PubMed]

86. Llauradó, G.; Morris, H.J.; Lebeque, Y.; Venet, G.; Fong, O.; Marcos, J.; Fontaine, R.; Cos, P.; Bermúdez, R.C. Oral administration of an aqueous extract from the oyster mushroom Pleurotus ostreatus enhances the immunonutritional recovery of malnourished mice. Biomed. Pharmacol. 2016, 83, 1456-1463. [CrossRef]

87. Gao, W.; Sun, Y.; Chen, S.; Zhang, J.; Kang, J.; Wang, Y.; Wang, H.; Xia, G.; Liu, Q.; Kang, Y. Mushroom lectin enhanced immunogenicity of HBV DNA vaccine in C57BL/6 and HBsAg-transgenic mice. Vaccine 2013, 31, 2273-2280. [CrossRef] 
88. Jesenak, M.; Majtan, J.; Rennerova, Z.; Kyselovic, J.; Banovcin, P.; Hrubisko, M. Immunomodulatory effect of pleuran ( $\beta$-glucan from Pleurotus ostreatus) in children with recurrent respiratory tract infections. Int. Immunopharmacol. 2013, 15, 395-399. [CrossRef] [PubMed]

89. Habtemariam, S. Trametes versicolor (Synn. Coriolus versicolor) polysaccharides in cancer therapy: Targets and efficacy. Biomedicines 2020, 8, 135. [CrossRef] [PubMed]

90. Wang, K.L.; Lu, Z.M.; Mao, X.; Chen, L.; Gong, J.S.; Ren, Y.; Geng, Y.; Li, H.; Xu, H.Y.; Xu, G.H.; et al. Structural characterization and anti-alcoholic liver injury activity of a polysaccharide from Coriolus versicolor mycelia. Int. J. Biol. Macromol. 2019, 137, 1102-1111. [CrossRef]

91. Yang, S.F.; Zhuang, T.F.; Si, Y.M.; Qi, K.Y.; Zhao, J. Coriolus versicolor mushroom polysaccharides exert immunoregulatory effects on mouse B cells via membrane Ig and TLR-4 to activate the MAPK and NF-kB signaling pathways. Mol. Immunol. 2015, 64, 144-151. [CrossRef] [PubMed]

92. Awadasseid, A.; Eugene, K.; Jamal, M.; Hou, J.; Hago, A.M.; Gamallat, Y.; Meyiah, A.; Bamba, D.; Gift, C.; Abdalla, M.; et al. Effect of Coriolus versicolor glucan on the stimulation of cytokine production in sarcoma-180-bearing mice. Biomed. Rep. 2017, 7, 567-572. [CrossRef]

93. Shi, S.H.; Yang, W.T.; Huang, K.Y.; Jiang, Y.L.; Yang, G.L.; Wang, C.F.; Li, Y. $\beta$-glucans from Coriolus versicolor protect mice against S. typhimurium challenge by activation of macrophages. Int. J. Biol. Macromol. 2016, 86, 352-361. [CrossRef] [PubMed]

94. Chu, K.K.W.; Ho, S.S.S.; Chow, A.H.L. Coriolus versicolor: A medicinal mushroom with promising immunotherapeutic values. J. Clin. Pharmacol. 2002, 42, 976-984. [CrossRef]

95. Saleh, M.H.; Rashedi, I.; Keating, A. Immunomodulatory properties of coriolus versicolor: The role of polysaccharopeptide. Front. Immunol. 2017, 8, 1087. [CrossRef] 